\title{
Fluorescent Labeling of SNAP-Tagged Proteins in Cells
}

\author{
Gražvydas Lukinavičius, Luc Reymond, and Kai Johnsson
}

\begin{abstract}
One of the most prominent self-labeling tags is SNAP-tag. It is an in vitro evolution product of the human DNA repair protein $O^{6}$-alkylguanine-DNA alkyltransferase (hAGT) that reacts specifically with benzylguanine (BG) and benzylchloropyrimidine (CP) derivatives, leading to covalent labeling of SNAP-tag with a synthetic probe (Gronemeyer et al., Protein Eng Des Sel 19:309-316, 2006; Curr Opin Biotechnol 16:453-458, 2005; Keppler et al., Nat Biotechnol 21:86-89, 2003; Proc Natl Acad Sci U S A 101:9955$9959,2004)$. SNAP-tag is well suited for the analysis and quantification of fused target protein using fluorescence microscopy techniques. It provides a simple, robust, and versatile approach to the imaging of fusion proteins under a wide range of experimental conditions.
\end{abstract}

Key words Snap-tag, Synthetic fluorophores, Living and fixed cells, Covalent labeling, Self-labeling tags, Fluorescence microscopy, Episomal protein expression

\section{Introduction}

A powerful approach for studying protein function inside living cells is their specific labeling with synthetic fluorescent reporter groups $[1,2]$. One of the most frequently used methodologies is based on so-called self-labeling tags. A popular example of such a tag is SNAP-tag, an in vitro evolution product of the human DNA repair protein $O^{6}$-alkylguanine-DNA alkyltransferase (hAGT) that reacts specifically and rapidly with benzylguanine (BG) and benzylchloropyrimidine (CP) derivatives (Fig. la), leading to covalent labeling of SNAP-tag with a synthetic probe [3-9]. Proteins of interest (POI) fused to SNAP-tag react only once with a single substrate molecule generating fluorescently tagged fusion proteins (Fig. lb). The nontoxic nature of BG and $\mathrm{CP}$ derivatives together with the molecular specificity of SNAP-tag makes it suitable for a broad range of applications including in vivo imaging (Fig. 2). Examples of recent applications include single molecule $[10,11]$ and super-resolution imaging $[12,13]$, analysis of protein function [14], targeted protein inactivation [15], protein-protein interactions 
a<smiles>N=C1C=CC2(c3cc(C(=O)NCc4ccc(COc5cc(Cl)nc(N)n5)cc4)ccc3C(=O)O)C(=C1)Oc1cc(N)ccc12</smiles><smiles></smiles><smiles>CN(C)c1ccc(C2=C(c3cc(C(=O)NCc4ccc(COc5nc(N)nc6[nH]cnc56)cc4)ccc3C(=O)O)c3ccc([N+](C)(C)C)cc3[Si](C)(C)C2)c(OCc2ccc([N+](C)(C)C)cc2)c1</smiles>

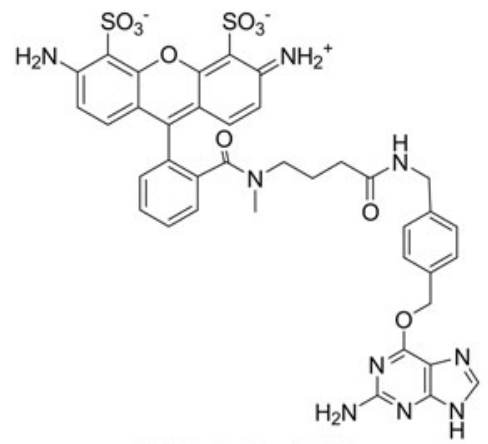

SNAP-Surface 848
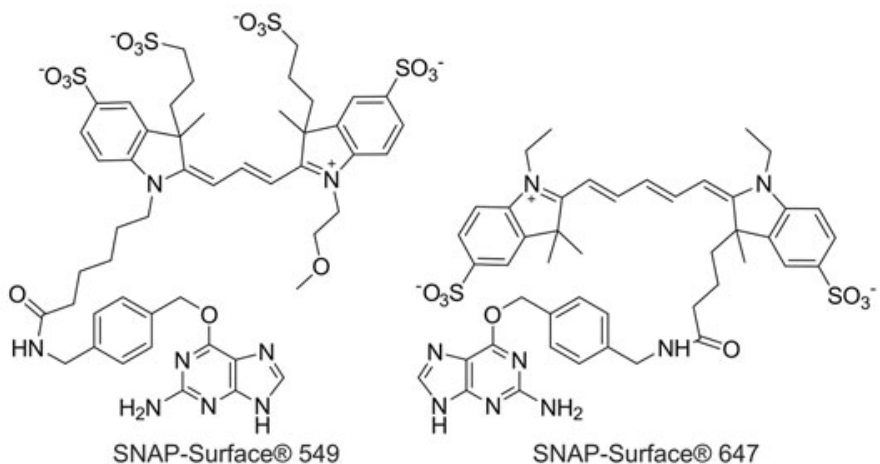

SNAP-Surface® 647

b

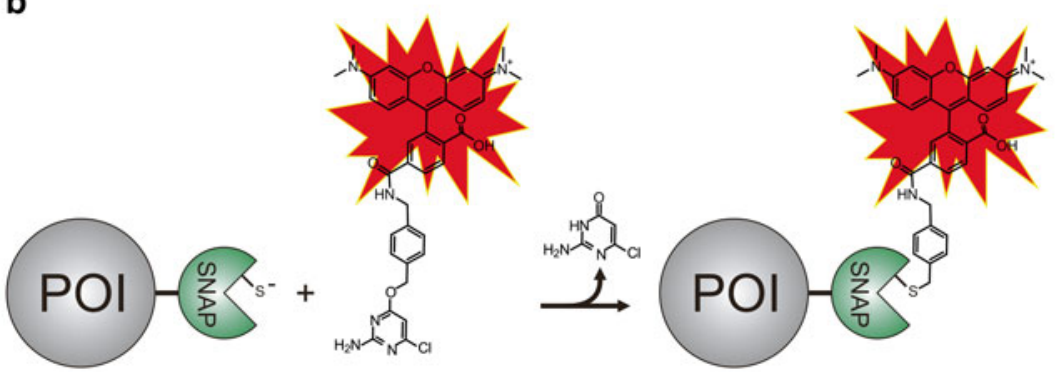

Fig. 1 SNAP-tag protein labeling technology. (a) Chemical structures of fluorescent substrates used for SNAPtagged protein labeling: top row-examples of cell permeable substrates, bottom row-examples of cell nonpermeable substrates. (b) Scheme showing principle of protein of interest (POI) labeling via SNAP-tag

$[16,17]$, protein-drug interactions $[18,19]$, and the determination of protein half-life in animals [20]. Additionally, similar hAGTbased tag, named CLIP-tag, was developed recently [21]. It reacts specifically with $O^{2}$-benzylcytosine derivatives. SNAP-tag and CLIP-tag possess orthogonal substrate specificities, SNAP and CLIP fusion proteins can be labeled simultaneously and specifically 

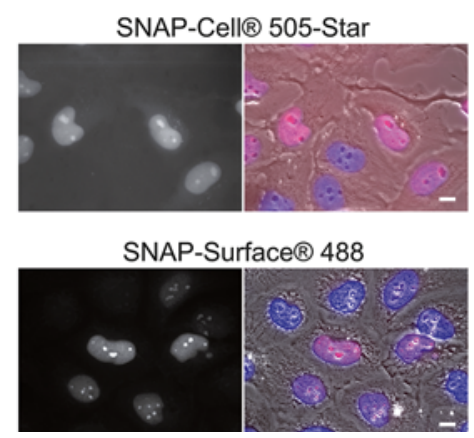
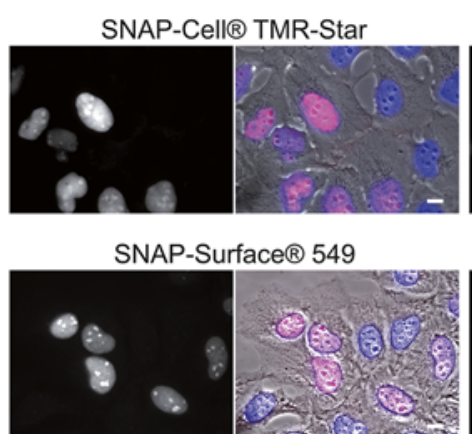

SNAP-Cell囚 647-SiR

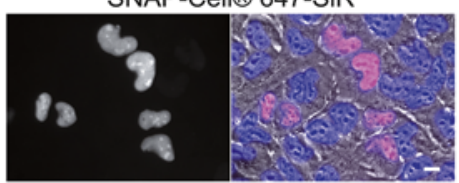

SNAP-Surface $\circledast 647$

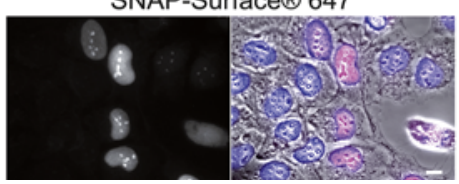

Fig. 2 Staining performance of SNAP-tag substrates. Live U20S (top row) or fixed cells (bottom row) expressing nuclear localized SNAP-tag construct were stained with the substrates and Hoechst 33342. In the overlay image Hoechst 33342 is presented in blue, SNAP-tag substrate red, and transmission phase contrast image in gray. Panel to the left of overlay image represents SNAP-tag substrate image in gray. Scale bar $10 \mu \mathrm{m}$ (color figure online)

with different molecular probes in living cells. Examples of such application include simultaneous labeling of two different fusion proteins [21], selective cross-linking (S-CROSS) of interacting proteins $[16,17,19]$ and simultaneous measurement of protein SUMOylation at the single-molecule level [22].

\section{Materials}

Prepare all solutions using ultrapure water (prepared by purifying deionized water to attain a resistance of $18 \mathrm{M} \Omega \mathrm{cm}$ at $25^{\circ} \mathrm{C}$ ) and analytical-grade reagents. All water solutions are filtered through $0.22 \mu \mathrm{m}$ pore size membrane syringe filter directly after preparation.

1. U2OS cells from ATCC (HTB-96 $\left.{ }^{\mathrm{TM}}\right)$. It is recommended to prepare multiple frozen stocks after obtaining cells. Details on cell line cultivation and cryopreservation are available on ATCC web site.

2. Growth medium: high-glucose DMEM without glutamine, pyruvate, and phenol red. Before usage, supplement with $10 \%$ fetal bovine serum, $2 \mathrm{mM}$ GlutaMAX ${ }^{\mathrm{TM}}-\mathrm{I}$ and $1 \mathrm{mM}$ sodium pyruvate (see Note 1 ).

3. Trypsin/EDTA solution. Aliquote and store at $-20{ }^{\circ} \mathrm{C}$.

4. Opti-MEM ${ }^{\circledR}$ I reduced serum medium. Store at $+4{ }^{\circ} \mathrm{C}$.

5. Lipofectamine 2000. Store at $+4^{\circ} \mathrm{C}$. Freezing might change performance.

6. $1 \mathrm{mg} / \mathrm{ml}$ Puromycin stock solution $(1,000 \times)$. Aliquote and store at $-20{ }^{\circ} \mathrm{C}$.

7. $0.1 \mathrm{mg} / \mathrm{ml}$ Doxycycline stock solution $(1,000 \times)$. Aliquote and store at $-20^{\circ} \mathrm{C}$. 
8. $1 \mathrm{mg} / \mathrm{ml}$ Hoechst 33342 stock solution $(1,000 \times)$. Aliquote and store at $-20^{\circ} \mathrm{C}$.

9. PBS buffer without $\mathrm{Ca}^{2+}, \mathrm{Mg}^{2+}$, or phenol red. Store in the dark at room temperature.

10. Hanks balanced salt solution (HBSS) without phenol red. Store in the dark at room temperature.

11. Lyophilized powder of albumin from bovine serum (BSA). Store at $+4{ }^{\circ} \mathrm{C}$.

12. EGTA, molecular biology grade. Store at room temperature.

13. PIPES, molecular biology grade. Store at room temperature.

14. BRB80 extraction buffer: $80 \mathrm{mM}$ K-PIPES, $\mathrm{pH} 6.8,1 \mathrm{mM}$ $\mathrm{MgCl}_{2} ; 1 \mathrm{mM}$ EGTA, $0.2 \%$ IGEPAL-630. Prepare freshly before experiment from the stock solutions of $0.5 \mathrm{M} \mathrm{K}$-PIPES, $\mathrm{pH} 6.8,1 \mathrm{M} \mathrm{MgCl} 2,0.5 \mathrm{M}$ EGTA, and IGEPAL-630 (see Notes 2 and $\mathbf{3}$ ).

15. Methanol, analytical reagent grade. Store at $-20^{\circ} \mathrm{C}$ ( see Note 4).

16. $1 \% \mathrm{w} / \mathrm{v}$ BSA solution in PBS. Store at $+4{ }^{\circ} \mathrm{C}$.

17. PBS-T wash buffer: PBS buffer supplemented with $0.05 \%$ TX-100.

18. Staining buffer: PBS buffer supplemented with $1 \% \mathrm{w} / \mathrm{v}$ BSA. DMSO solution of the substrate is added just before labeling procedure at concentration indicated in protocol part.

19. SNAP-tag substrates: SNAP-Cell ${ }^{\circledR}$ 505-Star (New England Biolabs), SNAP-Cell ${ }^{\circledR}$ TMR-Star (New England Biolabs), SNAP-Surface ${ }^{\circledR} 488$ (New England Biolabs), SNAP-Surface ${ }^{\circledR}$ 549 (New England Biolabs), and SNAP-Surface ${ }^{\circledR} 647$ (New England Biolabs). SNAP-Cell ${ }^{\circledR}$ 647-SiR (New England Biolabs) substrate synthesis is described in [23]. SNAP-tag substrates are dissolved in dry DMSO at final concentration of $1 \mathrm{mM}$ and stored at $-20^{\circ} \mathrm{C}$.

20. Mounting media: $90 \mathrm{ml}$ of glycerol mixed with $10 \mathrm{ml}$ of $10 \times$ PBS and dissolved 2-4 g of propyl gallate (see Note 5).

\section{Methods}

Carry out all procedures at room temperature unless otherwise specified.

\subsection{Generation of Cell Lines Expressing SNAP- Tagged Protein}

1. U2OS cells are used for generation of cell lines expressing SNAP-tagged proteins of interest. Cells are cultured in growth medium in a humidified $5 \% \mathrm{CO}_{2}$ incubator at $37^{\circ} \mathrm{C} .10 \mathrm{ml}$ of medium is used for $25 \mathrm{~cm}^{2}$ dish (see Note 6).

2. Prepare U2OS cells for transfection by splitting the cultured cells $24 \mathrm{~h}$ before transfection. Remove growth medium 
from confluent monolayer of cells in $25 \mathrm{~cm}^{2}$ dish. Wash cells with $5-10 \mathrm{ml}$ of PBS buffer and add $1 \mathrm{ml}$ of trypsin/ EDTA solution. Incubate for $5 \mathrm{~min}$ at $37^{\circ} \mathrm{C}$ and suspend detached cells in $11 \mathrm{ml}$ of growth medium. Prepare six-well plate containing $2 \mathrm{ml}$ of fresh growth medium in each well. Add $1 \mathrm{ml}$ of cell suspension to each well and incubate overnight ( see Note 7).

3. Next day dissolve 3-4 $\mu$ l of Lipofectamine 2000 and $2-4 \mu \mathrm{g}$ of DNA (pEBTet plasmid) in $100 \mu \mathrm{l}$ Opti-MEM I separately. Incubate for $5 \mathrm{~min}$ at room temperature. Prepare Lipofectamine 2000 and DNA complex by mixing both components and incubating for $15 \mathrm{~min}$ at room temperature (see Notes $\mathbf{8}$ and $\mathbf{9}$ ).

4. Prepare U2OS cells for transfection by replacing growth medium with $1 \mathrm{ml}$ of Opti-MEM I medium. Add prepared Lipofectamine 2000 and DNA complex solution and incubate for $6 \mathrm{~h}$ in a humidified $5 \% \mathrm{CO}_{2}$ incubator at $37^{\circ} \mathrm{C}$.

5. After $6 \mathrm{~h}$ replace Opti-MEM I medium with growth medium and incubate for additional $24-48 \mathrm{~h}$ in a humidified $5 \% \mathrm{CO}_{2}$ incubator at $37^{\circ} \mathrm{C}$ ( see Note 10).

6. Episomal plasmid pEBTet contains gene which renders transfected U2OS cells resistant to puromycin. Select for these cells by replacing growth medium with growth medium containing $1 \mu \mathrm{g} / \mathrm{ml}$ of puromycin. Selective medium has to be replaced each 2 days for duration of 4-6 days ( see Note 11).

7. Wash cells with $2 \mathrm{ml}$ of PBS buffer and add $0.4 \mathrm{ml}$ of trypsin/ EDTA solution. Incubate for $5 \mathrm{~min}$ at $37^{\circ} \mathrm{C}$, suspend detached cells, and transfer suspension into $25 \mathrm{~cm}^{2}$ dish with $10 \mathrm{ml}$ of growth medium and $1 \mu \mathrm{g} / \mathrm{ml}$ puromycin. Selected cells can be passaged every $4-5$ days ( $1: 10$ dilution) for about 2 months without major loss of transgene expression level (see Note 12).

\subsection{Labeling of SNAP-Tagged Proteins in Living Cells}

1. Prepare U2OS cells for microscopy by splitting the cultured cells $24-48 \mathrm{~h}$ before experiment. Remove growth medium from confluent monolayer of cells in $25 \mathrm{~cm}^{2}$ dish. Wash cells with $5-10 \mathrm{ml}$ of PBS buffer and add $1 \mathrm{ml}$ of trypsin/EDTA solution. Incubate for $5 \mathrm{~min}$ at $37^{\circ} \mathrm{C}$ and suspend detached cells in $11 \mathrm{ml}$ of growth medium (see Notes 13 and 14).

2. Prepare glass bottom six-well plate containing $2 \mathrm{ml}$ of fresh growth medium supplemented with $1 \mu \mathrm{g} / \mathrm{ml}$ puromycin and $0.1 \mu \mathrm{g} / \mathrm{ml}$ doxycycline in each well. Add $0.5 \mathrm{ml}$ of cell suspension to each well of plate. Incubate in a humidified $5 \% \mathrm{CO}_{2}$ incubator at $37^{\circ} \mathrm{C}$ for $24-48 \mathrm{~h}$ ( see Note 15).

3. Stain cells with cell permeable substrates by replacing growth medium with growth medium containing $0.3-5 \mu \mathrm{M}$ substrate. $1 \mu \mathrm{g} / \mathrm{ml}$ Hoechst 33342 can be included in the growth 


\subsection{Labeling of SNAP-Tagged Proteins in Fixed Cells}

\subsection{Labeling of SNAP-Tagged Proteins for Stimulated Emission Depletion (STED) Microscopy}

medium together with substrate (see Note 16). Incubate cells for $\mathrm{l} \mathrm{h}$ in a humidified $5 \% \mathrm{CO}_{2}$ incubator at $37{ }^{\circ} \mathrm{C}$ (see Note 17). Afterwards wash cells two times with $1 \mathrm{ml}$ of HBSS followed by 3-5 min incubation at room temperature. Replace HBSS after last wash with growth medium and incubate for additional $\mathrm{l} \mathrm{h}$ in a humidified $5 \% \mathrm{CO}_{2}$ incubator at $37^{\circ} \mathrm{C}$. Samples are ready for living cell imaging after this step.

1. Prepare cells for fixation, remove the growth medium, and add precooled to $-20{ }^{\circ} \mathrm{C}$ methanol and incubate for 3-10 min at $-20{ }^{\circ} \mathrm{C}$ in freezer (see Notes 18 and 19). Take six-well plate from freezer and wash two times cells with $2 \mathrm{ml}$ PBS buffer.

2. Incubate for $60 \mathrm{~min}$ in $2 \mathrm{ml}$ of $1 \% \mathrm{BSA}$ in PBS solution (see Note 20). Remove BSA solution and stain DNA by incubating with $1 \mathrm{ml}$ of $1 \mu \mathrm{g} / \mathrm{ml}$ Hoechst 33342 PBS solution for 1 min at room temperature. Wash excess of dye three times with $2 \mathrm{ml}$ PBS-T wash buffer.

3. SNAP-tagged proteins can also be labeled after methanol fixation ( see Note 21). Replace PBS with $1 \mathrm{ml}$ of staining buffer containing cell not permeable SNAP-tag substrate $(0.5-2 \mu \mathrm{M})$. Incubate for $l \mathrm{~h}$ at room temperature (see Note 22). Wash excess of dye $2-3$ times (incubating $3-5 \mathrm{~min}$ each time) with $2 \mathrm{ml}$ PBS-T wash buffer.

4. This step is optional and can be performed if additional antibody-based staining is needed (see Note 23). Remove PBS-T wash buffer and put $0.5 \mathrm{ml}$ of primary antibodies diluted in PBS with $1 \%$ BSA. Incubate samples overnight at $4{ }^{\circ} \mathrm{C}$. Wash excess of antibody three times 3-5 min with $1 \mathrm{ml}$ PBS-T wash buffer and add dilutions of secondary antibodies in PBS with $1 \%$ BSA. Incubate for $4-6 \mathrm{~h}$ at room temperature. Wash excess of antibody 3-5 min times with $1 \mathrm{ml}$ PBS-T wash buffer. Samples are ready for imaging after last wash (see Note 24).

Stimulated emission depletion (STED) microscopy [24] becomes more and more popular among the biologists who want to investigate cellular processes beyond the diffraction limit. Recent developments of fluorophores [17, 23, 25], parallelization of acquisition [26], time-resolved detection [27], and multicolor imaging [28, 29] pave the way to myriads of biological applications. Sample preparation for the STED microscopy is the same as described above (see Subheadings 3.2 and 3.3). However, only rhodamineclass fluorophores are recommended to be used. They display good enough photostability and brightness to be used for STED imaging (see Note 25). Image comparison of SNAP-tagged centrosomal proteins obtained with microscope operating in confocal or STED mode is provided in Fig. 3. 


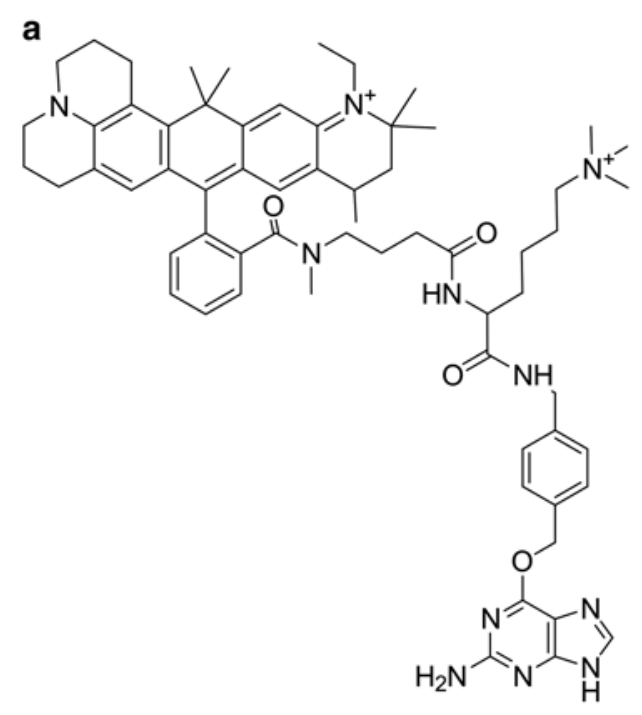

BG-Atto647N<smiles></smiles>

SNAP-Cell囚 647-SiR

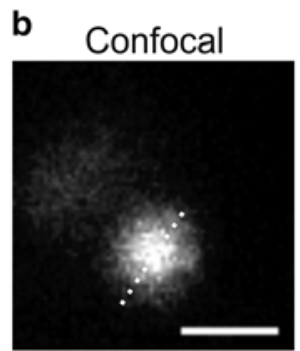

SNAP-Cep41

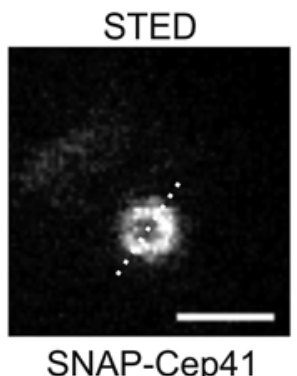

SNAP-Cep41

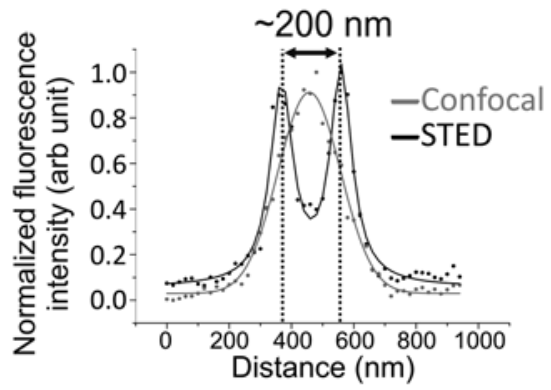

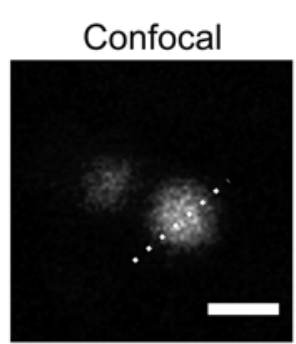

SNAP-Cep63

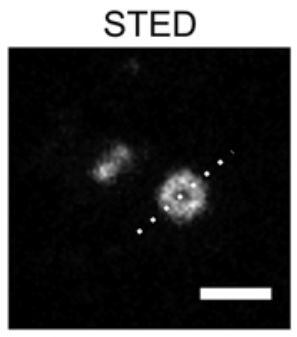

SNAP-Cep63

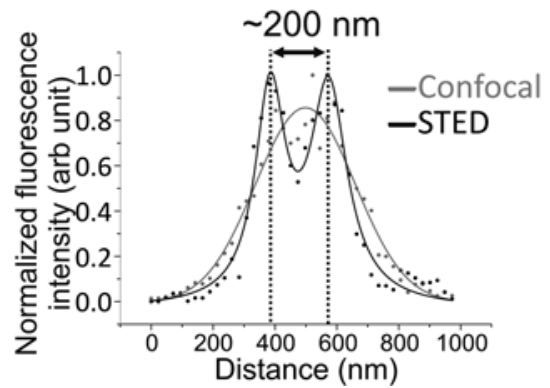

Fig. 3 STED imaging of SNAP-tagged proteins. (a) Chemical structures of STED compatible fluorescent substrates used for SNAP-tagged protein labeling: BG-Atto647N—example of cell nonpermeable substrate, SNAP-Cell ${ }^{\circledR} 647-S i R$ - example of cell permeable substrate. (b) Comparison of confocal and STED images of SNAP-tagged centrosomal proteins. SNAP-Cep41 expressing cells stained with SNAP-Cell ${ }^{\circledR}$ 647-SiR and imaged without fixing. SNAP-Cep63 expressing cells stained with BG-Atto647N after fixation. Left panel shows obtained images and profile line, right pane/ shows intensity profile of the line. Note, that improvement in resolutions leads to detection of doughnut shaped structure 


\section{Notes}

1. Phenol red is interfering with imaging of living cells and cells should be cultivated in the medium without it. Alternatively, cells can be propagated in growth medium containing phenol red, but this medium has to be replaced by fresh growth medium just before imaging experiment.

2. $0.5 \mathrm{M}$ K-PIPES stock: $15.1 \mathrm{~g}$ of piperazine- $N, N^{\prime}$-bis (2-ethanesulfonic acid) in $90 \mathrm{ml}$ of deionized water. Adjust $\mathrm{pH}$ to 6.8 with $10 \mathrm{M}$ potassium hydroxide. Long standing K-PIPES solution tends to develop yellow-brown color, but it is not interfering with quality of obtained results.

3. $0.5 \mathrm{M}$ EGTA solution: $19.0 \mathrm{~g}$ of ethylene glycol-bis(2aminoethylether)- $N, N, N^{\prime}, N^{\prime}$-tetraacetic acid in $90 \mathrm{ml}$ of deionized water. Adjust $\mathrm{pH}$ to 7.0 using $10 \mathrm{M}$ sodium hydroxide. EGTA displays low solubility in water as free acid and dissolves completely when $\mathrm{pH}$ is close to 7.0.

4. Cold methanol can be supplemented with $5 \mathrm{mM}$ EGTA pH 7.0 solution in order to improve cytoskeleton structure preservation during fixation.

5. Dissolving propyl gallate in $90 \%$ glycerol solution might take long time. It is recommended to sonicate solution or place tube in $+50{ }^{\circ} \mathrm{C}$ water bath and periodically mix it.

6. It is recommended to use U2OS cell line for generation of SNAP-tagged protein expressing cells since there is considerable variation of expression level in-between difference cell lines [30]. For example, HEK 293 displays higher expression levels and HeLa displays lower expression levels compared to U2OS.

7. Added volume of trypsinated cells is adjusted so that $\sim 20 \%$ confluence is obtained if all cells are adhered to the surface of new dish.

8. Transfection efficiency is dependent on many factors. It is recommended to determine the best transfection conditions before performing this experiment.

9. Generation of episomal expression vector pEBTet encoding SNAP-tagged protein of interest (POI). Expression vector is generated by $L R$ recombination via att $L$ and att $R$ sites which is a part of Gateway ${ }^{\circledR}$ Cloning Technology available commercially from Life Technologies (Fig. 4). It contains Epstein-Barr virus origin of replication (oriP), which is capable of continuous episomal propagation in the mammalian cell lines in the presence of plasmid-encoded EBNA-1 protein. Cells without episome could be easily eliminated by selection with puromycin. Protein expression is driven from inducible $\mathrm{CMV}+\mathrm{TetO} 2$ 

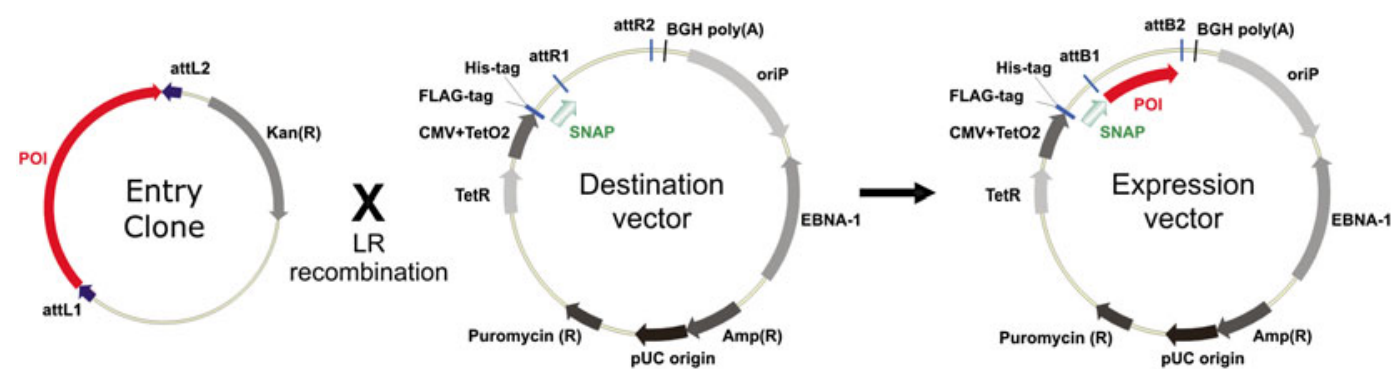

Fig. 4 Construction of the fused proteins expressing plasmids using Gateway ${ }^{\mathrm{TM}}$ cloning system

promoter [31]. Additionally, destination/expression vector can be propagated in E. coli cells since it contains pUC origin of replication and antibiotic resistance genes. Construction of destination vector is described in [17]. Entry clone plasmids are commercially available from Life technologies or GeneCopoeia.

10. Prolonged exposure to Opti-MEM I and Lipofectamine 2000 complexes result in considerable death of the cells. U2OS cell line is very well tolerating up to $6 \mathrm{~h}$ exposure, but it cannot be incubated overnight.

11. Puromycin is an aminonucleoside antibiotic, which causes premature chain termination during translation. Resistance gene encodes puromycin $\mathrm{N}$-acetyltransferase which inactivates cytotoxic puromycin by acetylating it [32].

12. Expression of transgene is not stable due to silencing by various mechanisms. It is recommended not to split cells more then 10-15 times during the experiment.

13. For obtaining good quality microscopy images it is necessary that cell culture is not reaching complete confluence at the day of imaging. It is recommended to start with $\sim 10-20 \%$ of confluence $48 \mathrm{~h}$ before the imaging experiment.

14. Do not consume all the cells when setting up of an imaging experiment. The remaining cell suspension can be used for cell line propagation. This allows replication of experimental data.

15. Episomal pEBTet expression vector contains modified CMV promoter which is triggered "ON" in the presence of tetracycline or doxycycline in the medium. Keep tetracycline or doxycycline concentrations as low as possible since they display certain toxicity [33].

16. Hoechst 33342 counterstaining is recommended to include in most of the imaging experiments since it produces strong fluorescence signal, which is convenient for finding the cells and focusing. 
17. It is recommended to use low concentrations $(0.3-0.5 \mu \mathrm{M})$ of fluorescent substrates. High concentrations will result in higher background staining which is difficult to eliminate even with extensive washing. Fluorogenic SNAP-Cell ${ }^{\circledR}$ 647-SiR substrate is an exception and can be applied at concentrations up to $5 \mu \mathrm{M}$ without need of extensive washing. Properties of cell permeable substrates are listed in Table 1 .

18. SNAP-tag is highly stable and retains its activity even after fixation with cold methanol or paraformaldehyde. Fixation by cold methanol procedure is described here in more details, but paraformaldehyde or other fixatives can be used depending on which cell structure has to be preserved [35].

19. For the visualization of cell skeleton it is recommended to include preextraction step with BRB80 extraction buffer before applying cold methanol $[12,17]$. It is done by replacing growth medium with $2 \mathrm{ml}$ of BRB extraction buffer for $0.5 \mathrm{~min}$ at room temperature. Cold methanol is applied directly after this step.

20. Blocking with $1 \%$ BSA in PBS reduces background staining in all the following steps. Hoechst 33342 staining can be combined together with incubation with $1 \%$ of BSA in PBS.

21. SNAP-tag can be labeled with cell permeable substrates before fixation and covalent labeling survives fixation procedure very well. In general, labeling before fixation gives stronger specific signal compared to postfixation labeling [17].

22. It is recommended to use low concentrations $(0.5-2 \mu \mathrm{M})$ of fluorescent substrates. All cell impermeable substrates are highly charged molecules with low off-target binding, but prolonged exposure to high concentrations of them will result in higher background staining which elimination requires extensive washing. Properties of cell impermeable substrates are listed in Table 2.

\section{Table 1}

Properties of common cell permeable SNAP-tag substrates

\begin{tabular}{|c|c|c|c|c|c|c|}
\hline Substrate name & Excitation (nm) & Emission (nm) & QYa & $\begin{array}{l}\varepsilon 10^{4} \\
\left(\mathrm{~cm}^{-1} \mathrm{M}^{-1}\right)\end{array}$ & $\begin{array}{l}\text { Rate constant } 10^{3} \\
\left(\mathrm{M}^{-1} \mathrm{~s}^{-1}\right)\end{array}$ & Ref. \\
\hline SNAP-Cell ${ }^{\circledast} 505$-Star & 504 & 532 & 0.92 & 7.4 & 12.4 & [34] \\
\hline SNAP-Cell ${ }^{\circledR}$ TMR-Star & 554 & 580 & 0.68 & 9.1 & 15.5 & [34] \\
\hline SNAP-Cell ${ }^{\circledR} 647-S i R$ & 650 & 670 & 0.39 & 10.0 & 20.0 & [23] \\
\hline
\end{tabular}

${ }^{\mathrm{a}} \mathrm{Of}$ the unconjugated dye 
Table 2

Properties of common cell impermeable SNAP-tag substrates

\begin{tabular}{|c|c|c|c|c|c|c|}
\hline Substrate name & Excitation (nm) & Emission (nm) & QYa & $\begin{array}{l}\varepsilon 10^{4} \\
\left(\mathrm{~cm}^{-1} \mathrm{M}^{-1}\right)\end{array}$ & $\begin{array}{l}\text { Rate constant } 10^{3} \\
\left(\mathrm{M}^{-1} \mathrm{~s}^{-1}\right)\end{array}$ & Ref. \\
\hline SNAP-Surface $^{\circledR} 488$ & 506 & 526 & 0.80 & 9.0 & 12.1 & [36] \\
\hline SNAP-Surface ${ }^{\circledR} 549$ & 560 & 575 & n.d. & 15 & 11.1 & [36] \\
\hline SNAP-Surface ${ }^{\circledR} 647$ & 660 & 673 & 0.25 & 25 & n.d. & {$[8]$} \\
\hline BG-Atto647N & 644 & 669 & 0.65 & 15 & 2.9 & [17] \\
\hline
\end{tabular}

${ }^{\mathrm{a}} \mathrm{Of}$ the unconjugated dye

23. SNAP-tag labeling is not interfering with antibody staining. Both techniques can be combined to obtain multicolor images $[12,17]$.

24. Fixed samples do not require special mounting media for wide field microscopy. Suggested fluorophores are stable enough in simple PBS solution. Samples prepared for confocal or STED microscopy should be mounted in $90 \%$ glycerol in PBS containing $2-4 \% \mathrm{w} / \mathrm{v}$ of propyl gallate.

25. SNAP-Surface ${ }^{\circledR} 549$ and SNAP-Surface ${ }^{\circledR} 647$ substrates are derivatives of cyanines and bleach extremely fast under STED imaging conditions.

\section{References}

1. Giepmans BN, Adams SR, Ellisman MH, Tsien RY (2006) The fluorescent toolbox for assessing protein location and function. Science 312:217-224

2. van de Linde S, Heilemann M, Sauer M (2012) Live-cell super-resolution imaging with synthetic fluorophores. Annu Rev Phys Chem 63:519-540

3. Gronemeyer T, Chidley C, Juillerat A, Heinis C, Johnsson K (2006) Directed evolution of $\mathrm{O}^{6}$-alkylguanine-DNA alkyltransferase for applications in protein labeling. Protein Eng Des Sel 19:309-316

4. Gronemeyer T, Godin G, Johnsson K (2005) Adding value to fusion proteins through covalent labelling. Curr Opin Biotechnol 16:453-458

5. Keppler A, Gendreizig S, Gronemeyer T, Pick $\mathrm{H}$, Vogel H, Johnsson K (2003) A general method for the covalent labeling of fusion proteins with small molecules in vivo. Nat Biotechnol 21:86-89

6. Keppler A, Pick H, Arrivoli C, Vogel H, Johnsson K (2004) Labeling of fusion proteins with synthetic fluorophores in live cells. Proc Natl Acad Sci U S A 101:9955-9959
7. Hinner MJ, Johnsson K (2010) How to obtain labeled proteins and what to do with them. Curr Opin Biotechnol 21:766-776

8. Keppler A, Arrivoli C, Sironi L, Ellenberg J (2006) Fluorophores for live cell imaging of AGT fusion proteins across the visible spectrum. Biotechniques 41:167-170, 172, 174-175

9. Reymond L, Lukinavicius G, Umezawa K, Maurel D, Brun MA, Masharina A, Bojkowska K, Mollwitz B, Schena A, Griss R, Johnsson K (2011) Visualizing biochemical activities in living cells through chemistry. Chimia (Aarau) 65:868-871

10. Breitsprecher D, Jaiswal R, Bombardier JP, Gould CJ, Gelles J, Goode BL (2012) Rocket launcher mechanism of collaborative actin assembly defined by single-molecule imaging. Science 336:1164-1168

11. Hoskins AA, Friedman LJ, Gallagher SS, Crawford DJ, Anderson EG, Wombacher R, Ramirez N, Cornish VW, Gelles J, Moore MJ (2011) Ordered and dynamic assembly of single spliceosomes. Science 331:1289-1295

12. Dellagiacoma C, Lukinavicius G, Bocchio N, Banala S, Geissbuhler S, Marki I, Johnsson K, 
Lasser T (2010) Targeted photoswitchable probe for nanoscopy of biological structures. Chembiochem 11:1361-1363

13. Jones SA, Shim SH, He J, Zhuang X (2011) Fast, three-dimensional super-resolution imaging of live cells. Nat Methods 8:499-508

14. Foraker AB, Camus SM, Evans TM, Majeed SR, Chen CY, Taner SB, Correa IR Jr, Doxsey SJ, Brodsky FM (2012) Clathrin promotes centrosome integrity in early mitosis through stabilization of centrosomal ch-TOG. J Cell Biol 198:591-605

15. Keppler A, Ellenberg J (2009) Chromophoreassisted laser inactivation of alpha- and gammatubulin SNAP-tag fusion proteins inside living cells. ACS Chem Biol 4:127-138

16. Gautier A, Nakata E, Lukinavicius G, Tan KT, Johnsson K (2009) Selective cross-linking of interacting proteins using self-labeling tags. J Am Chem Soc 131:17954-17962

17. Lukinavicius G, Lavogina D, Orpinell M, Umezawa K, Reymond L, Garin N, Gonczy P, Johnsson K (2013) Selective chemical crosslinking reveals a Cep57-Cep63-Cepl52 centrosomal complex. Curr Biol 23:265-270

18. Chidley C, Haruki H, Pedersen MG, Muller E, Johnsson K (2011) A yeast-based screen reveals that sulfasalazine inhibits tetrahydrobiopterin biosynthesis. Nat Chem Biol 7:375-383

19. Haruki H, Gonzalez MR, Johnsson K (2012) Exploiting ligand-protein conjugates to monitor ligand-receptor interactions. PLoS One 7:e37598

20. Bojkowska K, Santoni de Sio F, Barde I, Offner $S$, Verp S, Heinis C, Johnsson K, Trono D (2011) Measuring in vivo protein half-life. Chem Biol 18:805-815

21. Gautier A, Juillerat A, Heinis C, Correa IR Jr, Kindermann M, Beaufils F, Johnsson K (2008) An engineered protein tag for multiprotein labeling in living cells. Chem Biol 15:128-136

22. Yang Y, Zhang CY (2013) Simultaneous measurement of SUMOylation using SNAP /CLIPtag-mediated translation at the single-molecule level. Angew Chem Int Ed Engl 52:691-694

23. Lukinavicius $\mathrm{G}$, Umezawa $\mathrm{K}$, Olivier $\mathrm{N}$, Honigmann A, Yang G, Plass T, Mueller V, Reymond L, Correa IR Jr, Luo ZG, Schultz C, Lemke EA, Heppenstall P, Eggeling C, Manley $S$, Johnsson K (2013) A near-infrared fluorophore for live-cell super-resolution microscopy of cellular proteins. Nat Chem 5:132-139

24. Hell SW, Wichmann J (1994) Breaking the diffraction resolution limit by stimulated emission: stimulated-emission-depletion fluorescence microscopy. Opt Lett 19:780-782

25. Kolmakov K, Wurm CA, Hennig R, Rapp E, Jakobs S, Belov VN, Hell SW (2012)
Red-emitting rhodamines with hydroxylated, sulfonated, and phosphorylated dye residues and their use in fluorescence nanoscopy. Chemistry 18:12986-12998

26. Chmyrov A, Keller J, Grotjohann T, Ratz M, d'Este E, Jakobs S, Eggeling C, Hell SW (2013) Nanoscopy with more than 100,000 'doughnuts'. Nat Methods 10:737-740

27. Vicidomini G, Schonle A, Ta H, Han KY, Moneron G, Eggeling C, Hell SW (2013) STED nanoscopy with time-gated detection: theoretical and experimental aspects. PLoS One 8:e54421

28. Gottfert F, Wurm CA, Mueller V, Berning S, Cordes VC, Honigmann A, Hell SW (2013) Coaligned dual-channel STED nanoscopy and molecular diffusion analysis at $20 \mathrm{~nm}$ resolution. Biophys J 105:L01-L03

29. Pellett PA, Sun X, Gould TJ, Rothman JE, Xu MQ, Correa IR Jr, Bewersdorf J (2011) Twocolor STED microscopy in living cells. Biomed Opt Express 2:2364-2371

30. Qin JY, Zhang L, Clift KL, Hulur I, Xiang AP, Ren BZ, Lahn BT (2010) Systematic comparison of constitutive promoters and the doxycycline-inducible promoter. PLoS One 5:e10611

31. Bach M, Grigat S, Pawlik B, Fork C, Utermohlen O, Pal S, Banczyk D, Lazar A, Schomig E, Grundemann D (2007) Fast set-up of doxycycline-inducible protein expression in human cell lines with a single plasmid based on Epstein-Barr virus replication and the simple tetracycline repressor. FEBS J 274:783-790

32. Vara J, Perez-Gonzalez JA, Jimenez A (1985) Biosynthesis of puromycin by Streptomyces alboniger: characterization of puromycin $\mathrm{N}$-acetyltransferase. Biochemistry 24:8074-8081

33. Sekeroglu ZA, Afan F, Sekeroglu V (2012) Genotoxic and cytotoxic effects of doxycycline in cultured human peripheral blood lymphocytes. Drug Chem Toxicol 35:334-340

34. Correa IR, Baker B, Zhang A, Sun L, Provost CR, Lukinavicius G, Reymond L, Johnsson K, $\mathrm{Xu}$ MQ (2013) Substrates for improved livecell fluorescence labeling of SNAP-tag. Curr Pharm Des 19:5414-5420

35. Luther PW, Bloch RJ (1989) Formaldehydeamine fixatives for immunocytochemistry of cultured Xenopus myocytes. J Histochem Cytochem 37:75-82

36. Sun X, Zhang A, Baker B, Sun L, Howard A, Buswell J, Maurel D, Masharina A, Johnsson K, Noren CJ, Xu MQ, Correa IR Jr (2011) Development of SNAP-tag fluorogenic probes for wash-free fluorescence imaging. Chembiochem 12:2217-2226 